\title{
Katarzyna Szymańska
}

Politechnika Łódzka

e-mail: katarzyna.szymanska@p.lodz.pl

\section{IDENTYFIKACJA I OCENA CZYNNIKÓW \\ STYMULUJĄCYCH I OGRANICZAJĄCYCH \\ OTWARTOŚĆ ORGANIZACYJNĄ \\ W SEKTORZE PRZEMYSŁÓW KREATYWNYCH}

\section{IDENTIFICATION AND ASSESSMENT \\ OF FACTORS STIMULATING AND LIMITING ORGANIZATIONAL OPENNESS IN THE SECTOR OF CREATIVE INDUSTRIES}

DOI: $10.15611 / \mathrm{pn} .2018 .538 .33$

JEL Classification: D21, D23, D91, L22, O33

Streszczenie: W niniejszym opracowaniu zawarto rozważania na temat relacji łączących otwartość organizacyjną z funkcjonowaniem sektora przemysłu kreatywnego. Celem artykułu była próbą identyfikacji i ocena czynników stymulujących i ograniczających otwartość organizacyjną w sektorze przemysłów kreatywnych. Dążąc do realizacji tego celu, w artykule wykorzystano część danych pochodzących z badań pilotażowych przeprowadzonych na próbie 150 przedsiębiorstw z różnych branż kreatywnych zlokalizowanych w województwie łódzkim. Bazując na wynikach badań oraz ocenie źródeł wtórnych, starano się pokazać, że przemysły kreatywne stanowią bardzo szerokie spektrum aktywności, które musi być realizowane w różnych formach otwartości organizacji oraz jest ukierunkowane na różne cele. Badania wykazały, że respondenci w pełni rozumieją konieczność otwartości ich przedsiębiorstw, jednak dodatkowo oczekują budowania przez politykę wsparcia (sferę administracji publicznej i sferę nauki) otwartej przestrzeni do innowacyjności, eksperymentowania i przedsiębiorczości.

Słowa kluczowe: otwartość organizacyjna, przemysł kreatywny, innowacyjność, przedsiębiorczość.

Summary: This study contains considerations on the relationship between organizational openness and the functioning of the creative industry sector. The aim of the article was an attempt to identify and evaluate the stimulating factors and limit the organizational openness in the creative industries sector. In pursuit of this objective, the article uses part of the data from pilot studies carried out on a sample of 150 enterprises from various creative industries located in the Lodz region. Based on the results of research and the evaluation of secondary sources, efforts were made to show that creative industries constitute a very wide spectrum of activities that have to be implemented in various forms of organization's openness and are oriented towards different goals. Research has shown that respondents fully understand 
the necessity of openness of their enterprises, but they also expect to build an open space for innovation, experimentation and entrepreneurship through support policy (the sphere of public administration and the sphere of science).

Keywords: organizational openness, creative industry, innovation, entrepreneurship.

\section{Wstęp}

Rozwój i dynamika zmian istotnych dla strategii kształtującej przewagę konkurencyjną różnych organizacji, również z przemysłu kreatywnego, wymaga ciągłej oceny, a także gotowości i odwagi działań związanych z ich otwartością na szeroko rozumiane otoczenie. Otwartość organizacji to nowa cecha dla wszystkich przedsiębiorstw, stanowiąca dziś duże wyzwanie dla zarządzających. W ramach otwartości tradycyjne relacje oparte na hierarchii zmieniają się w kierunku otwartych - nie tylko relacji z klientami, lecz także z innymi interesariuszami. Zauważa się też ścisły, synergiczny związek zachodzący między otwartością organizacyjną a rozwojem przemysłów kreatywnych. Przemysły kreatywne, których tworzywem jest twórczość artystyczna i działalność kulturalna i które zalicza się w XXI wieku do sektorów najbardziej ekspansywnych, tworzą nowy, ważny sektor gospodarki dużych miast, aglomeracji miejskich i obszarów metropolitalnych. Przyjęto więc, że dynamika działań wynikająca z modelu otwartości może stać się prorozwojową strategią dla przemysłu kreatywnego, którego główną częścią składową jest rozwijanie i tworzenie podażowych łańcuchów działalności. Dlatego też celem artykułu jest próba identyfikacji i ocena czynników stymulujących i ograniczających otwartość organizacyjną w sektorze przemysłów kreatywnych.

\section{Czym jest otwartość organizacji?}

Znaczenie otwartości organizacyjnej jest podkreślane w wielu współczesnych opracowaniach [Albors-Garrigos, Barbera 2012; Baldwin, Gelletly 2003]. Termin ten należy postrzegać jako kluczowe źródło przewagi konkurencyjnej przedsiębiorstw, gdyż przez kreowanie cech otwartości w różnych obszarach działalności przedsiębiorstw możliwe jest dynamiczne reagowanie na zmiany zachodzące w zmieniającym się otoczeniu [Caligiuri i in. 2000, s. 24-27]. W literaturze termin ten określa złożony i długi proces, na który składa się szereg relacji będących warunkiem zaistnienia otwartości wewnątrz organizacji oraz jej otoczeniu. Procesy te mogą dotyczyć różnych obszarów, np. komunikacji, zarządzania, wytworzenia i dystrybucji produktu/usługi, obszaru marketingu lub rozwiązań organizacyjnych itp. W tym miejscu należy zaznaczyć, że cecha, tj. otwartość, jak i inne bezpośrednio z nią powiązane (tj. otwartość na komunikację, na współtworzenie, na działanie itp.) uznawane są za kluczowe w różnych modelach służących do badania efektywności organizacji [Lewin, Minton 1986, s. 522]. Otwartość można więc zdefiniować jako logiczną 
sekwencję działań otwierających organizację na otoczenie, a występujących w ramach procesu biznesowego, którego głównym zadaniem jest tworzenie wartości dla przedsiębiorstwa, ich właścicieli oraz zewnętrznych partnerów. Co oznacza szeroko rozumianą zdolność przystosowania się do funkcjonowania w zmiennych warunkach otoczenia, współpracy z różnego typu partnerami, a poprzez to gotowość systematycznej, a przy tym świadomie kreowanej dynamiki wielu procesów biznesowych, w tym przewagi konkurencyjnej przedsiębiorstw. W myśl tego otwartość organizacyjna związana jest z szeregiem procesów, które zachodzą w każdym przedsiębiorstwie i obejmują działania opierające się na [Foster, Carrie 2015, s. 15-19]':

- tworzeniu nowych pomysłów dzięki ciągłemu rozpoznawaniu potrzeb klientów (zarówno zewnętrznych, jak i wewnętrznych), motywowaniu, promowaniu, sprzyjaniu i kreowaniu wśród pracowników możliwości do tworzenia nowych pomysłów itp.;

- zmianie procesów produkcyjnych adekwatnie do wymagań i potrzeb otoczenia (w tym klientów), ciągłym wprowadzaniu nowych technologii i metod zarządzania;

- rozwoju przedsiębiorstw poprzez szeroką koordynację we wszystkich fazach jego cyklu życia i przydatności tych działań dla różnego typu interesariuszy $\mathrm{z}$ różnych sfer życia gospodarczego, tj. administracji, nauki i biznesu;

- zwiększaniu wartości istniejących lub nowo powstałych produktów/usług;

- zarządzaniu, które musi mieć przełożenie na konkretne działania zachodzące tak wewnątrz, jak i na zewnątrz przedsiębiorstwa, prowadzące do wyróżnienia firmy na rynku, a poprzez to zdobycia przewagi konkurencyjnej.

Opisane działania można uznać z jednej strony za mierniki oceny, z drugiej zaś wyznaczniki kierunków/poziomu rozwoju otwartości przedsiębiorstw. Wprowadzanie tych działań do przedsiębiorstw pozwala na wzrost stopnia otwartości danego przedsiębiorstwa. Stopień ten można oceniać z perspektywy wielu płaszczyzn wewnętrznych i zewnętrznych. Do wewnętrznych uwarunkowań rozwoju otwartości organizacyjnej przedsiębiorstw należą m.in.: kadra (jej wiedza, doświadczenia, umiejętności i kwalifikacje pracowników oraz sposób zarządzania dostępnymi zasobami, zarządzanie informacją, osoby współpracujące z przedsiębiorstwem), aktywność firmy w zakresie badań i rozwoju, zaawansowanie technologiczne oraz jakość i nowoczesność infrastruktury technicznej.

Zewnętrzne uwarunkowania rozwoju otwartości zależą głównie od partnerów zewnętrznych: firmy konkurencyjne, klienci i dostawcy czy wyższe uczelnie, jednostki badawczo-rozwojowe i inni. Ich gotowość do współpracy i dzielenia się wiedzą, wypracowany poziom zaufania, którym darzą partnerów biznesowych, czy ich orientacja na klienta, konkurencję, dostawców itp., to tylko niektóre z częściej spotykanych cech ich otwartości. Dlatego aby przedsiębiorstwa były otwarte, ich menedżerowie muszą ciągle uczyć się, jak efektywnie zarządzać relacjami z otoczeniem, jak i kiedy

${ }^{1}$ Szerzej na ten otwartości organizacji zob. [Adamik 2018, s. 880-896]. 
je zmieniać, jak pokonywać bariery, które je blokują, oraz jakie mechanizmy wybrać, aby wdrażać skutecznie otwartość organizacyjną. Zawsze jednak, aby otworzyć organizację na zewnątrz, najpierw muszą być stworzone warunki do otwartości wewnątrz przedsiębiorstwa.

Otwartość organizacyjną można więc uznać za główną zasadę, która wyznacza postawę przedsiębiorstwa nie tylko wobec pracowników, klientów czy konkurentów, lecz także całego otoczenia. Wdrożenie tej idei do przedsiębiorstw wymaga zatem pełnej sprawności operacyjnej, czyli zdolności przełożenia strategii na procesy, systemy i struktury, oraz umiejętności właściwego reagowania na sytuacje nieoczekiwane, zwłaszcza na okazje rynkowe.

\section{Przemysł kreatywny}

Opisaną otwartość organizacyjną należy więc uznać za strategię działania, która może zapewnić przedsiębiorstwom również z sektora kreatywnego rozwój i względnie trwałą przewagę konkurencyjną. Co ważne, otwartość przedsiębiorstw uznaje się za kluczowy czynnik wzrostu konkurencyjności gospodarki europejskiej zgodny $z$ dokumentem UE Europa 2020. Dodatkowo w tym samym dokumencie zwraca się uwagę na fakt istnienia i ważność przedsiębiorstw z branży kultury i branży twórczej (cultural and creative industries), czyli przemysłu kreatywnego. Przemysły kreatywne są od niedawna postrzegane jako grupa podmiotów tworząca nowy sektor w gospodarce narodowej. Przeciętne tempo rozwoju tego sektora jest o około 13\% większe od tempa rozwoju całej gospodarki Unii Europejskiej. W związku z tym przyjęto, że między otwartością organizacji a rozwojem przemysłów kreatywnych zachodzi ścisła synergia. Przemysł kreatywny (creative industries), definiowany jako przedsiębiorstwa kreatywne, jest terminem ostatnio często pojawiającym się w polskiej literaturze. Bogactwo desygnatów definicji i pojęć w obszarze tego zjawiska powoduje utożsamianie go z terminami: sektory kreatywne (creative doctor), sektory kultury (culture sectory) i przemysły kultury (cultural industries). Można więc stwierdzić, że definicja przemysłów kreatywnych powstała na styku pojęć: kultura, ekonomia, sztuka i rynek. W literaturze zaznacza się, że od lat 40. do 70. ubiegłego wieku termin ten odnosił się tylko do obszaru ściśle związanego z kulturą, a o kreatywności jako kluczowym czynniku rozwoju zaczęto mówić dopiero w latach 80. XX wieku. Przełomem było wprowadzenie do literatury naukowej przez Gunnara Törnqvista pojęcia creative milieu, które zaczęto tłumaczyć jako środowisko kreatywne lub środowisko twórcze. Bardzo ważnym momentem okazały się lata 90. ubiegłego wieku, kiedy w Wielkiej Brytanii powstała jedna z najczęściej wykorzystywanych do dziś interpretacji sektora kreatywnego. Definicja ta została opisana w dokumencie opracowanym przez zespół ds. przemysłów kreatywnych (Creative Industries Taskforce). W raporcie tym sektory kreatywne odnoszą się do „działań, które biorą się z indywidualnej kreatywności i talentu, i które mają zarazem potencjał kreowania bogactwa oraz zatrudnienia poprzez wytwarzanie i wykorzystywanie 
praw własności intelektualnej" [Creative Industries Mapping Document 1998, s. 3]. W dokumencie tym wyszczególniono listę sektorów kreatywnych, do których zaliczono 13 branż: reklama, film i wideo, architektura, muzyka, rynek sztuki i antyków, sztuki performatywne, gry komputerowe i wideo, rynek wydawniczy, rzemiosło, oprogramowanie, wzornictwo, radio i telewizja, projektowanie mody [Törnqvist $1983]^{2}$. Podana lista, choć jest aktualna do dziś, przez badaczy tematu jest często uzupełniana lub minimalizowana w zależności od branż charakterystycznych dla danego państwa, regionu czy miasta [Szymańska 2017].

Jak można zauważyć, pojęcie sektora/przemysłu kreatywnego w krótkim okresie ewoluowało, a wskazane cechy przemysłów kreatywnych ściśle odnoszą się do opisanych wcześniej procesów, które musi realizować przedsiębiorstwo w ramach otwartości organizacji. Dodatkowo w realizacji kluczowych działań prowadzonych w przemysłach kreatywnych uczestniczy szereg czynników wewnętrznych i zewnętrznych, które determinują otwartość organizacji. W przypadku czynników wewnętrznych można wskazać, że otwartość tych sektorów opiera się na kreatywności i szerokich umiejętnościach ludzi tworzących innowacyjne pomysły (przykładowo: dźwięki, teksty i obrazy), które rozpowszechniają i dostarczają na rynek towary i usługi ${ }^{3}$. Przedsiębiorstwa w tym sektorze muszą więc przejawiać się dużą dynamiką rozwoju, interdyscyplinarnością i otwartością działalności w porównaniu z innymi branżami, stymulując innowacyjny i kreatywny rozwój całej gospodarki. Będąc umiejscowione gdzieś między sztuką, kulturą, biznesem i technologią oraz związując się z obszarem działalności gospodarczej, stawiają na indywidualną kreatywność, umiejętności i talent, a w konsekwencji tworzenie własności intelektualnej [UNCTAD 2008]. Według T. Rickardsa przez otwarte działania sektory te „promują ucieczkę od zastoju myślowego", podkreślając jednocześnie rolę twórczego myślenia w procesie podejmowania decyzji, jak i w rozwiązywaniu problemów [Rickards 1998]. Sektory

\footnotetext{
${ }^{2}$ Inną równie ważną definicję sektora kreatywnego opracowano na zlecenie Komisji Europejskiej. Na podstawie badań prowadzonych w tym obszarze przez instytut Kern European Affairs (KEA) opracowano raport The Economy of Culture in Europe, zgodnie z którym sektor kreatywny można podzielić na dwa rodzaje działalności: sektor przemysłu kultury i sektor przemysłu kreatywnego. Sektor przemysłu działający w obszarze kultury został uznany tu za rodzaj działań kulturalnych, których rezultat jest czysto artystyczny; w obszarze tym znalazły się też tradycyjne działa sztuki. Natomiast za sektory przemysłu kreatywnego uznano wszelkie działania, które wykorzystują kulturę jako wartość dodaną w wytwarzaniu produktów pozakulturalnych.

${ }^{3}$ Klasyfikacja towarów i usług kreatywnych jest dostępna w statystykach prowadzonych przez Organizację Narodów Zjednoczonych (UNCTAD). Dane towarów bazują na systemie klasyfikacji Harmonized System (HS). System ten umożliwia klasyfikację ponad 98\% produktów znajdujących się w handlu zagranicznym co najmniej w 177 krajach. Liczba kodów HS zawartych w każdej z grup kreatywnych towarów jest następująca: projektowanie - 120 kodów, wydawnictwo - 15 kodów, nowe media -8 kodów, rzemiosło -60 kodów, media audiowizualne -2 kody, sztuka wizualna -17 kodów, sztuka sceniczna -7 kodów. Natomiast usługi kreatywne opierają się na klasyfikacji Extended Balance of Payments Services Classification (EBOPS), stworzonej na podstawie wytycznych Międzynarodowego Funduszu Walutowego.
} 
te będąc dostawcami twórczego kapitału początkowego, wpływają na zwiększenie potencjału innowacyjnego przedsiębiorstw [Miles, Green 2008]. Z kolei zewnętrzne uwarunkowania rozwoju, otwartość dla „kreatywnych” zależą od szerokiej współpracy z różnymi interesariuszami, która odbywa się w celu łączenia sztuki, kultury, nowoczesnych technologii i biznesu oraz stanowi podstawowy element przewagi konkurencyjnej nowoczesnych krajów, których gospodarki już dawno przestały być np. konkurencyjne cenowo.

W tym miejscu należy zwrócić uwagę na fakt istnienia czterech kluczowych płaszczyzn, które jednocześnie potwierdzają konieczność realizowania otwartości organizacyjnej przez przedsiębiorstwa z sektorów kreatywnych (obszary te opisano w European Competitiveness Report), wpływając na inne gałęzie gospodarki.

Pierwszą płaszczyznę oddziaływania tworzą tzw. efekty ekonomiczne, które dotyczą bezpośredniego i wymiernego wkładu przedsiębiorstw z sektorów kreatywnych w gospodarkę, w odniesieniu do m.in. wzrostu poziomu zatrudnienia, eksportu czy wartości dodanej tego sektora. Efekt ten jest ściśle związany ze wzrostem udziału tego sektora w PKB, co jest szczególnie ważne w dobie kryzysu i rosnącego bezrobocia. Przemysł kreatywny jest więc wyjątkowym obszarem otwartej aktywności ekonomicznej. Jego specyfikę charakteryzują niepewność i ryzyko podejmowanych działań. Jest to także sektor o wysokiej dynamice, w którym następują częste zmiany w zakresie popytu i podaży na określone produkty i usługi. $Z$ tego względu niezbędny jest ciągły proces monitoringu i reagowania na sytuację rynkową. Ciekawe jest, że polski przemysł kreatywny zarówno pod względem liczby zatrudnionych, jak i udziału w tworzeniu dochodu narodowego znajduje się na poziomie zbliżonym do innych państw europejskich [Etmanowicz i in. 2012, s. 37].

Druga płaszczyzna związana jest tzw. efektem rozlewania (spillover) szeregu korzyści, jakie z istnienia i działalności przedsiębiorstw w tym sektorze czerpią nie tylko ich przedstawiciele, lecz także cała gospodarka. W obszarze tym kluczową wartość tego efektu stanowi wzrost poziomu stymulowania rozwoju regionalnego, która jest określona przez ocenę wpływu efektów regionalnych oraz popytem na nie w innych sektorach gospodarki. Właściwym przykładem jest tu tzw. otwartość w zakresie pozyskiwania i dzielenia się wiedzą, która polega na absorpcji wiedzy $\mathrm{z}$ jednego przedsiębiorstwa do drugiego. Opisane działania ułatwiają budowanie przewagi konkurencyjnej przedsiębiorstw opierającej się na unikalności, co stanowi kluczową cechę produktów z tego sektora.

Trzecią płaszczyzną oddziaływań przedsiębiorstw z sektorów kreatywnych są działania związane $\mathrm{z}$ bezpośrednim wkładem $\mathrm{w}$ symulowanie innowacyjności tego sektora i innych dziedzin gospodarki. Działania takie polegają na dostarczeniu innym przedsiębiorstwom gotowych innowacyjnych rozwiązań/projektów lub samych pomysłów dla powstawania nowych produktów, usług, procesów czy technologii. Wzajemne relacje zachodzące pomiędzy innowacyjnością przedsiębiorstw sektora kreatywnego a pozostałymi interesariuszami otoczenia można opisać za pomocą skłonności tych przedsiębiorstw do otwartości na współpracę z szeroko rozumianym 
otoczeniem (innymi funkcjonującymi podmiotami, w tym również z dużymi organizacjami, instytucjami otoczenia biznesu, jednostkami badawczymi itp.).

Z kolei czwarta płaszczyzna działania odpowiada za oddziaływanie przedsiębiorstw z sektora kreatywnego na: poprawę jakości życia, wzmacnianie poczucia tożsamości kulturowej i ogólnej satysfakcji mieszkańców danego miasta czy regionu oraz realizację szeregu ważnych innych celów społecznych. Efekty funkcjonowania przedsiębiorstw w tym obszarze mają zarówno wartość ekonomiczną dla danej gospodarki, jak i kulturową, gdyż wzmacniają poczucie tożsamości kulturowej mieszkańców, wiążąc ich z daną lokalizacją oraz zwiększając atrakcyjność danego miejsca [Szultka 2014, s. 14-23].

Reasumując, każda organizacja jest w inny sposób otwarta, a zatem można przyjąć, że cechy, które generują podstawowe warunki otwartości organizacji, tj.: przezroczystość, spójność/tożsamość, zdolność adaptacji, współpraca i społeczność, są cechami wspólnymi dla przedsiębiorstw w szczególności z sektora kreatywnego i innych sfer życia gospodarczego [Cox 2005]. W związku z tym konieczne jest budowanie wzorcowego modelu otwartości organizacyjnej, istotnego dla rozwoju przedsiębiorstw z przemysłu kreatywnego.

\section{Otwartość organizacyjna a przemysł kreatywny - wyniki badań}

Aby zrealizować cel opracowania, przeprowadzono w roku 2018 badania pilotażowe w sektorze przemysłów kreatywnych zlokalizowanych w województwie łódzkim. W obszarze prowadzonych prac empirycznych zrealizowano badania, w ramach których przeprowadzono wywiad telefoniczny wspomagany komputerowo (CATI) na próbie 150 firm reprezentujących różne branże (reklama, sztuki performatywne, architektura, oprogramowanie), działających w sektorze kreatywnym. Struktura branży, która była przeprowadzona w celu rozpoznania sektora przemysłów kreatywnych zlokalizowanych w województwie łódzkim, wskazała, że jest ona bardzo silnie zróżnicowana wewnętrznie w kategoriach forma organizacyjna i cel działania. W toku badań wyszczególniono różne formy organizacyjne, takie jak: jednoosobowa działalność gospodarcza, spółki cywilne, spółki z ograniczoną odpowiedzialnością. W badaniach uczestniczyły przedsiębiorstwa mikro (74\%), małe (18\%), średnie (8\%). Do badań wykorzystano kwestionariusz ankiety zawierający 36 pytań.

$\mathrm{W}$ jednej z części badań respondenci zidentyfikowali m.in. czynniki zewnętrzne i wewnętrzne wpływające na rozwój badanej firmy z sektora kreatywnego, które oceniono w stosunku do ich otwartości. Respondenci mogli podać więcej niż jeden czynnik. Zestawienie uzyskanych odpowiedzi prezentuje tabela 1.

W kolejnym etapie badań starano się zidentyfikować aktywność przedsiębiorstw na czterech opisanych płaszczyznach, które mogą potwierdzić stopień realizowania otwartości organizacyjnej przez respondentów z sektorów kreatywnych. Dla każdej z płaszczyzn uwzględniono główne czynniki, które respondenci ocenili w skali od $1-3$. 
Tabela 1. Czynniki zewnętrzne i wewnętrzne wpływające na rozwój badanej firmy z sektora kreatywnego

\begin{tabular}{|c|c|}
\hline Czynniki zewnętrzne & Czynniki wewnętrzne \\
\hline $\begin{array}{l}\text { - uwarunkowania systemu społeczno- } \\
\text { - gospodarczego i prawnego (37\% wskazań) } \\
\text { - ogólny poziom rozwoju gospodarczego } \\
\text { danego kraju, stopień otwartości gospodarki } \\
\text { i możliwości inwestycyjne ( } 38 \% \text { wskazań) } \\
\text { - sytuacja na rynku produktów kreatywnych } \\
\text { (42\% wskazań) } \\
\text { - wzrost stopnia konkurencji w sektorze } \\
\text { przemysłów kreatywnych (39\% wskazań) } \\
\text { - zasady i praktyka prowadzonej polityki } \\
\text { gospodarczej, w tym zwłaszcza polityki } \\
\text { dotyczącej rozwoju przemysłów kreatywnych } \\
\text { (38\% wskazań) } \\
\text { - tendencje rozwoju technologicznego } \\
\text { w skali globalnej i możliwości adaptacji } \\
\text { nowoczesnych technologii w kraju (36\% } \\
\text { wskazań) } \\
\text { - postęp w integracji regionalnej (europejskiej) } \\
\text { (31\% wskazań). }\end{array}$ & $\begin{array}{l}\text { - czynniki związane z doświadczeniem } \\
\text { przedsiębiorcy, tj. doświadczenie } \\
\text { w kierowaniu firmą, w pracy z ludźmi, pasja } \\
\text { i osiągnięcia właściciela itp. (73\% wskazań) } \\
\text { - czynniki wynikające z osobowości } \\
\text { przedsiębiorcy, tj. kreatywność, otwartość na } \\
\text { innowacje, chęć wyróżnienia się, otwartość } \\
\text { na nieformalne relacje współpracy (73\% } \\
\text { wskazań) } \\
\text { - czynniki związane z oczekiwaniami otoczenia, } \\
\text { np. klientów, dostawców, społeczności } \\
\text { lokalnych, adaptacja zasobów firmy do } \\
\text { potrzeb partnerów (79\% wskazań); } \\
\text { - wysoki poziom kreatywności działań (83\% } \\
\text { wskazań) } \\
\text { - wyniki finansowe firmy (72\% wskazań) } \\
\text { - czynniki związane z personelem firmy, } \\
\text { tj. wykształcona i kompetentna kadra, } \\
\text { motywacja do działania, efektywność pracy } \\
\text { zespołowej (67\% wskazań) } \\
\text { - czynniki lokalizacyjne: bliskość geograficzna } \\
\text { i częstotliwość kontaktów z partnerami (35\% } \\
\text { wskazań) } \\
\text { - kultura organizacyjna, klimat zaufania } \\
\text { i współpracy, kontraktowe więzi współpracy } \\
\text { z interesariuszami (51\% wskazá) }\end{array}$ \\
\hline
\end{tabular}

Źródło: opracowanie własne.

Tabela 2. Ocena płaszczyzny otwartości badanych przedsiębiorstw

\begin{tabular}{|l|l|c|}
\hline \multicolumn{1}{|c|}{ Płaszczyzna } & \multicolumn{1}{|c|}{ Opis zmiennych } & $\begin{array}{c}\text { Ocena średnia dla MSP (ocena } \\
\text { w skali 1-3) }\end{array}$ \\
\hline Efekt ekonomiczny & Wkład w gospodarkę kraju & 1,3 \\
\hline Efekt rozlewania & $\begin{array}{l}\text { Otwartość w zakresie } \\
\text { pozyskiwania i dzielenia się } \\
\text { wiedzą }\end{array}$ & 2,0 \\
\hline Relacje z interesariuszami & $\begin{array}{l}\text { Stopień współdziałania } \\
\text { z interesariuszami }\end{array}$ & 1,6 \\
\hline Jakość życia & $\begin{array}{l}\text { Czynny udział w organizowaniu } \\
\text { np. imprez kulturalnych }\end{array}$ & 2,6 \\
\hline Razem/średnia ocena & & 1,3 \\
\hline
\end{tabular}

Źródło: opracowanie własne. 
Jak wynika z badań, próba zbadania potencjału sektora kreatywnego i poziomu jego oddziaływania na gospodarkę względem opisanych płaszczyzn nie dała jednoznacznych rezultatów. W większości respondenci nie wskazywali maksymalnych wartości dla żadnej z czterech płaszczyzn. Istotnym spostrzeżeniem uzupełniającym powyższe wyniki wydaje się fakt, że dodatkowo respondenci wskazywali kilka głównych korzyści dla ich otwartych relacji z różnymi grupami partnerów. Identyfikując te, które dotyczą roli otwartości dla rozwoju przedsiębiorstw kreatywnych różnej wielkości, należy podkreślić, że najczęściej:

- firmy mikro poprzez otwartość w relacjach z otoczeniem: generują lepszą reputację/wizerunek firmy (30,9\%), budują wyższą zyskowność działań firmy $(33,7 \%)$ oraz zyskują możliwość realizacji nietypowych zleceń $(30,5 \%)$;

- firmy małe poprzez otwartość w relacjach z otoczeniem: budują lepszą reputację/wizerunek firmy (36,7\%), osiągają możliwość realizacji nietypowych działań $(38,3 \%)$, budują wyższą zyskowność działań firmy (45\%);

- firmy średnie poprzez otwartość w relacjach z otoczeniem: zyskują lepsze zaspokojenie potrzeb klienta $(32,4 \%)$, budują lepszą reputację/wizerunek firmy $(67,6 \%)$, odbiorcy osiągają lepszą pozycję konkurencyjną w regionie $(42,8 \%)$.

Wymienione przez respondentów korzyści można uznać za główne czynniki stymulujące otwartość organizacyjną w badanym sektorze. Generalnie w opinii ponad $80 \%$ badanych $(88,8 \%)$ ich otwarte relacje głównie z otoczeniem miały znaczenie dla dynamizowania ich rozwoju oraz przewagi konkurencyjnej, a w przypadku blisko 50\% $(48,2 \%)$ z nich odgrywały wręcz bardzo ważną rolę. Dodatkowo w większości $70 \%$ $(77,7 \%)$ respondenci wskazali, że w ramach działalności muszą prowadzić otwartą współpracę ze sferą nauki (są to otwarte relacje z przedstawicielami różnych uczelni zlokalizowanych w całym kraju), sferą administracji publicznej (np. w ramach pozyskania kapitałów) oraz ze sferą biznesu (np. realizując wspólne przedsięwzięcia). Choć jak wskazali respondenci, współpraca ta jest czasami utrudniona, to jednak jej motywy likwidują powstałe bariery. Do kluczowych motywów takiej współpracy respondenci zaliczyli:

- chęć pozyskiwania i tworzenia nowych rozwiązań, a także możliwość współpracy dla wdrażania nowych technologii, specyficznych dla reprezentowanej branży kreatywnej;

- ciągłą potrzebę wprowadzania nowych innowacyjnych produktów opartych na szczególnych preferencjach klientów;

- możliwość pozyskania nowych rozwiązań wpływających korzystnie na jakość i cenę produkowanych wyrobów;

- wymogi dynamicznego rynku przemysłu kreatywnego, szybkie zmiany preferencji nabywców;

- zdobycie nowych rynków zbytu.

Nie ulega więc wątpliwości, że sektor kreatywny, dzięki tworzeniu oryginalnej wiedzy, produktów i usług, może stanowić źródło wartości i przewagi dla nowoczesnej gospodarki. 
W dalszej części badań respondenci określili bariery ograniczające otwartość organizacyjną dla rozwoju firmy z sektora kreatywnego. Do głównych barier zaliczyli czynniki przedstawione $\mathrm{w}$ tabeli 3 .

Tabela 3. Bariery ograniczające otwartość organizacyjną firm z sektorów kreatywnych

\begin{tabular}{|r|l|c|c|c|}
\hline \multirow{2}{*}{ Lp. } & \multicolumn{1}{|c|}{ Opinia respondentów } & \multicolumn{2}{c|}{ SME N $=150(\%)$} & \\
\cline { 3 - 5 } & & $\begin{array}{c}\text { Firmy } \\
\text { mikro }\end{array}$ & $\begin{array}{c}\text { Firmy } \\
\text { małe }\end{array}$ & $\begin{array}{c}\text { Firmy } \\
\text { średnie }\end{array}$ \\
\hline 1. & Brak środków finansowych & 36 & 14 & 23 \\
\hline 2. & Brak kreatywności w działaniu & 12 & 18 & 28 \\
\hline 3. & Brak gotowości do podejmowania ryzyka & 34 & 41 & 36 \\
\hline 4. & Brak otwartości na zmiany (P) & 38 & 39 & 39 \\
\hline 5. & Brak nastawienia na szybkość i jakość & 33 & 37 & 41 \\
\hline 6. & Niska tolerancja niepewności & 36 & 28 & 29 \\
\hline 7. & Brak nastawienia na współpracę & 38 & 32 & 37 \\
\hline 8. & Niska motywacja zewnętrzna (niski wpływ partnerów & & & \\
\hline 9. & Bewnętrznych na innowacyjność firmy) & 14 & 25 & 19 \\
\hline 10. & Brak sprawnych kanałów komunikacyjnych & 24 & 33 & 38 \\
\hline
\end{tabular}

Źródło: opracowanie własne.

Jak można zauważyć, sektor kreatywny świadomie interpretuje czynniki zewnętrzne i wewnętrzne wpływające na ich otwartość oraz bariery utrudniające ten proces $\mathrm{w}$ relacjach z innymi podmiotami. W związku z tym, jak wskazywali w większości badani respondenci $(88,8 \%)$, budowanie systemu sprzyjającego likwidacji opisanych barier powinno być związane m.in. z:

- generowaniem popytu na produkty sektora kreatywnego, dzięki czemu może stać się on integralną częścią lokalnych, regionalnych i krajowych systemów gospodarczych;

- zapewnieniem łatwego dostępu do kapitału oraz zasobów ludzkich;

- budowaniem systemu instytucji wspierających jego funkcjonowanie itp.

\section{Zakończenie}

Interpretując wyniki zaprezentowanych badań, należy wskazać ich główne ograniczenia. Pierwsze z nich jest efektem wysokiego poziomu ogólności obszarów otwartości, co wynika z różnorodności branż, a tym samym konieczności możliwie uniwersalnego określenia czynników istotnych dla badanych przedsiębiorstw. Drugie ograniczenie ma związek z przyjętą metodą, gdyż badano opinie tylko jednej grupy respondentów, czyli właścicieli przedsiębiorstw. 
Poddając jednak ocenie wycinek prowadzonych badań, można stwierdzić, że działalność kreatywna z założenia i z definicji musi być bardziej otwarta od innych branż. Wymaga to od tego sektora ciągłej oceny czynników sprzyjających i ograniczających ich otwartość na różne relacje zachodzące w trakcie działalności tych przedsiębiorstw. Badania wykazały, że respondenci w pełni rozumieją konieczność otwartości ich przedsiębiorstw, jednak dodatkowo oczekują budowania np. przez politykę wsparcia otwartej przestrzeni do innowacyjności, eksperymentowania i przedsiębiorczości.

Dokładniejsze poznanie mechanizmów i procesów zachodzących w diadzie: otwartość organizacyjna a przemysł kreatywny motywuje do prowadzenia pogłębionych badań w tym zakresie. W szczególności ciekawym wyzwaniem badawczym byłoby zidentyfikowanie i ocena tych zależności na reprezentatywnej próbie przedsiębiorstw zlokalizowanych w różnych województwach Polski, a następnie krajach Europy. Takie badania dadzą przyczynek do konstrukcji otwartego modelu wsparcia tego sektora. Dzięki temu możliwe będzie uwolnienie potencjału polskiego sektora kreatywnego na inne kraje oraz stymulowanie i rozwijanie innych sektorów gospodarki narodowej. Zaprezentowane w artykule rozważania należy zatem traktować jako przyczynek do kolejnych poszukiwań badawczych.

\section{Literatura}

Adamik A., Nowicki M., Szymańska K., 2018, Openness to co-creation as a method of reducing the complexity of the environment and dynamizing companies' competitive advantages, Management \& Marketing, no 13 (2), s. 880-896.

Albors-Garrigos J., Rodriguez Barbera R., 2012, Impact of public funding on firms innovation performance. Analisis of internal and extrenal moderating factors, International Journal of Innovation Management.

Baldwin J., Gelletly G., 2003, Innovation Strategies and Performance in Small Firms, Edward Elgar, Cheltenham.

Baldwin R., 2003, Openness and growth: what's the empirical relationship, http://www.nber. org/papers/w9578 (15.09.2018).

Caligiuri P.M., Jacobs R.R., Farr J.L., 2000, The attitudinal and behavioral openness scale: Scale develop ment and construct validation, International Journal of Intercultural Relations, vol. 24, no 5.

Cox G., 2005, The Cox Review of Creativity in Business:Building on the UK's Strengths, http://www. hm-treasury.gov.uk/coxreview_index.htm (13.09.2018).

Creative Industries Mapping Document, 1998.

Edward T., Delbridge R., Munday M., 2005, Understanding innovation in small and medium-sized entereprises: a process manifest, Technovation, no 25, Cardiff.

Etmanowicz A., Trzebeński M., Martela B., 2012, Rekomendacje działań i kierunków wsparcia rozwoju przemystów kreatywnych $w$ województwie pomorskim. Podsumowanie prac grup ds. rekomendacji, Fundacja IMPACT, Urząd Marszałkowski Województwa Pomorskiego, Gdańsk.

Foster M., Carrie L., 2015, Managing the flow of talent through organizations - a boundary-less mode, Development and Learning in Organizations: An International Journal.

Lewin A.Y., Minton J.W., 1986, Determining organizational effectiveness: another look and agenda for research, Management System.

Miles I., Green L., 2009, Research report July 2008: Hidden innovation in the creative industries, NE- 
STA, London, http://www.nesta.org.uk/hidden-innovation-in-the-creative-industries/ (2.09.2018). Peters M., 2010, The Idea of Openness: Open Education and Education for Openness, [w:] Peters M., Besley T., Gibbons A., Žarnić B., Ghiraldelli P. (red.), The Encyclopaedia of Educational Philosophy and Theory, http://eepat.net/doku.php?id=open_education_and_education_for_openness (2.09.2018).

Rickards T., 1998, Creativity and Innovation: A Transatlantic Perspective, Creativity and Innovation Yearbook, t. 1, Manchester Business School.

Szymańska K., 2017, Uwarunkowania rozwoju sektorów kreatywnych, Management Forum, vol. 5, no 4, Wrocław.

Törnqvist G., 1983, Creativity and the renewal of regional life, [w:] Buttimer A. (red.), Creativity and Context, Lund Studies in Geography, B. Human Geography, nr 50.

UNCTAD 2008, Creative Economy Report 2008: The challenge of assessing the creative economy towards informed policy-making, United Nations, http://ssc.undp.org/creative_economy (2.04.2018). 